\title{
Characterization of textile dyeing effluent and its treatment using polyaluminum chloride
}

\author{
M. Rafiqul Islam ${ }^{1}$ - M. G. Mostafa ${ }^{1}[$
}

Received: 2 March 2020 / Accepted: 14 April 2020 / Published online: 23 April 2020

(c) The Author(s) 2020

\begin{abstract}
The study aimed to expose the level of pollution owing to textile dyeing effluents and assess the coagulant efficiency of polyaluminum chloride (PAC) for treating the textile dyeing effluents. The discharged of untreated textile dyeing effluents have severely polluted water and soils, threatened the entire environment. The study analyzed the discharged and treated effluents using standard methods of analysis. The optimized parameters of the coagulant PAC were the dose, contact time, temperature, and agitation speed. The color removal efficiency study observed that the coagulant PAC removed the color from 85 to $95 \%$ of three dyeing effluents at optimum conditions. The result showed that the maximum reduction of EC, TDS, TSS, COD, BOD, $\mathrm{Cl}^{-}, \mathrm{HCO}_{3}{ }^{-}$and $\mathrm{SO}_{4}{ }^{2-}$ were found to be 83.66, 85.7, 82.05, 82.05, 83.45, 66.91, 66.91 and 72.88\%, respectively. It also showed that the coagulant efficiently reduced heavy metals and the highest percentage of reduction achieved was 72.7 and 98.52 for $\mathrm{Fe}$ and $\mathrm{Pb}$, respectively, from the effluents. Hence, the PAC would be a potential coagulant for treating the textile dyeing effluents that help to build a sustainable environment.
\end{abstract}

Keywords BOD $\cdot$ Coagulant $\cdot$ COD $\cdot$ Effluents $\cdot$ PAC $\cdot$ Treatment

\section{Introduction}

Textile and dyeing factories play an incredibly imperative role in deteriorating the water quality by releasing their effluents in ponds, rivers, lakes, and oceans. Even a few amounts of dyes in water are vastly observable and objectionable (Crini 2006). Pollutants from textile dyeing industries change significantly and depend on the chemicals used in different dyeing and printing processes. The discharged untreated or poorly treated or diluted textile dyeing effluents on land surface and exterior water bodies could relocate a huge cost to the environment as well as to ecological disturbance and associated human health problems. Generally, industrial pollutants often differ the physicochemical characteristics, for example, temperature, acidity, salinity, turbidity of water bodies, leading to ecology alterations resulting in water becomes brackish. A study observed that high sulfate $\left(\mathrm{SO}_{4}{ }^{2-}\right)$ content in industrial effluents discharged near the drinking water supply can cause invigorating action

M. G. Mostafa

mostafa_ies@yahoo.com

1 Institute of Environmental Science, University of Rajshahi, Rajshahi 6205, Bangladesh
(Agarwal 1996). Besides, the chloride $\left(\mathrm{Cl}^{-}\right)$ion, which has always been used as a pollution pointer, might scratch the metallic pipes and agriculture products (Kumar, 1989; Lalove et al. 2000). As the textile dyeing effluent deteriorated the surface water quality, hence, it should be treated before discharging nearby surface water bodies. Recently, various treatment techniques, including adsorption (Makia et al. 1999; Ahmad and Ram 1992), precipitation (Duizbek and Kowal 1983), ozonization (Lin and Lin 1993), oxidation (Tan et al. 2000), and coagulation-flocculation (Bennett and Reeser 1998; Belukear and Jekel 1993) are developed for treating the effluents. Adsorption, flocculation, coagulation, precipitation, ozonization, irradiation, etc. are used as physical and chemical methods for the treatment of textile dyeing effluents (Soares et al. 2006; Wang et al. 2009a, b; Ozer et al. 2006; Shi et al. 2007). Coagulation is one of the most effective chemical methods to remove dyes and pigments from textile dyeing effluents (Gao et al. 2007; Golob et al. 2005). Chemical coagulation in textile dyeing effluent treatment involves the adding of chemicals to change the physical state of dissolved and suspended solids and assist their elimination by sedimentation. The coagulation process has been applying for many years because it is technologically suitable and cost-effective (Islam and Mostafa 2018a; 
Anjaneyulu et al. 2005; Golob et al. 2005). The study considered polyaluminum chloride (PAC) as an effective coagulant for removing the color from the textile dyeing effluents. The study selected three dyeing industries located in Narsingdi, Gazipur and BSCIC area of Rajshahi District as the areas have the hubs of textile dyeing and printing industries in Bangladesh. The objective of the study is to characterize the textile dyeing effluent and assess the color removal efficiency of the coagulant polyaluminum chloride (PAC).

\section{Materials and methods}

\section{Sample collection}

The study collected three textile dyeing effluents, namely Ef1 (Effluent of Narsingdi District), Ef2 (Effluent of Rajshahi District), Ef3 (Effluent of Gazipur District), from sampling locations of Narsingdi, Rajshahi and Gazipur Districts of Bangladesh. The samples were collected in a one-liter double cap acid-washed polythene bottles from three locations. Before sampling, every bottle was washed with watery acid and double distilled water and before real sampling, the bottles were rinsed with effluents to be sampled.

\section{Sample treatment}

All textile dyeing effluent samples were treated with coagulating agent PAC (Analytical Reagent Grade). A jar test apparatus was used in this study to determine the optimum condition. The color removal efficiency of the coagulant PAC was determined using optimized the parameters such as $\mathrm{pH}$ (3 to 11$)$, doses ( 50 to $600 \mathrm{mg} / \mathrm{L}$ ), agitation speed (30 to $150 \mathrm{rpm}$ ), initial dye dose (50 to $300 \mathrm{mg} / \mathrm{L}$ ) and temperature $\left(30\right.$ to $\left.50{ }^{\circ} \mathrm{C}\right)$. A definite dose of coagulant PAC were added to the desired volume of effluent containing beaker and immediately mixed with a magnetic stirrer for 1 to $2 \mathrm{~min}$. Then mixed slowly and finally, the mixed solution was allowed to settle for $30 \mathrm{~min}$. The color of the solution was measured after filtration of supernatant through Whatman No. 42 filter paper. The absorbance was measured using UV-spectrophotometer (SHIMADZU UV-mini1240). Percentage of color removal was calculated using the following equation:

$\%$ of color removal $=\frac{A_{\mathrm{o}}-A_{\mathrm{f}}}{A_{\mathrm{o}}} \times 100$

where $A_{\mathrm{o}}$ and $A_{\mathrm{f}}$ are the initial and final absorbance of the effluent, respectively.

The $\mathrm{pH}$ of the samples Ef1, Ef2 and Ef3 was kept as the original $\mathrm{pH}$ of the effluents $7.65,6.70$ and 8.10 , respectively. Then allowed to settle and the time of settlement was
30 min. The solution was then filtered (Arnold et al. 1992). All these tests were performed at temperature $30^{\circ} \mathrm{C}$ because the temperature is one of the important parameters on concentration, viscosity and therefore retained the volume of coagulant used. The temperature has a significant effect on pH calculation (APHA 1989). During the effluent's treatment, the PAC coagulant was controlled by the hydrolysis speciation (Dennett et al. 1996). Many monomeric and polymeric species of PAC coagulant have been produced during coagulation such as $\mathrm{Al}_{13}(\mathrm{OH})_{34}{ }^{5+}, \mathrm{Al}(\mathrm{OH})_{17}{ }^{4+}, \mathrm{Al}(\mathrm{OH})_{20}{ }^{4+}$, $\mathrm{Al}(\mathrm{OH})_{15}{ }^{3+}, \mathrm{Al}_{2}(\mathrm{OH})_{2}{ }^{4+}, \mathrm{Al}_{2}(\mathrm{OH})^{5+}, \mathrm{Al}_{4}(\mathrm{OH})_{8}{ }^{4+}, \mathrm{Al}_{13} \mathrm{O}_{4}$ $(\mathrm{OH})_{24}{ }^{7+}, \mathrm{Al}_{3}(\mathrm{OH})_{4}{ }^{5+}, \mathrm{Al}_{13}(\mathrm{OH})_{32}{ }^{7+}$, and $\mathrm{Al}_{14}(\mathrm{OH})^{8+}$, to name but a little bit (Amirtharajah and Mills 1982)). The tri-positive aluminum ion is converted into the negative aluminum ion in the aqueous solution gradually and is shown in Fig. 1 (Stumn and Morgan 1962).

\section{Sample analysis}

The collected samples were analyzed for some major parameters of the textile dyeing effluents including $\mathrm{pH}, \mathrm{EC}$, TSS, TDS, COD, BOD, chlorides, bicarbonates, sulfates, and heavy metals. TDS and TSS of the effluents were measured by the gravimetric oven drying method at $105{ }^{\circ} \mathrm{C}$. BOD of the effluents was determined by incubating the sample at $20{ }^{\circ} \mathrm{C}$ for 5 days followed by titration. COD was measured by the closed reflux method. Bicarbonates, chlorides, and sulfates were determined by complexometric titration, argentometric titration, and turbidity method, respectively. All the parameters after the treatment with PAC coagulants were measured, followed by the same methods, as discussed above. The textile dyeing effluent samples were preserved for analysis of heavy metals $(\mathrm{Cr}, \mathrm{Cu}, \mathrm{Fe}, \mathrm{Mn}, \mathrm{Zn}$, and $\mathrm{Pb})$ by acidification with concentration $\mathrm{HNO}_{3}$ and $\mathrm{HCl}(2 \mathrm{ml}$ $\mathrm{HNO}_{3}$ and $3 \mathrm{ml} \mathrm{HCl}$ ) of the solution and then stored at $5{ }^{\circ} \mathrm{C}$ till analyzed. All the metals were examined by the atomic absorption spectrophotometer using the air- $\mathrm{C}_{2} \mathrm{H}_{2}$ flame, as suggested by Chrislarsen (1982). The analytical results of all the water samples were thus evaluated following the norms prescribed under EPA standards.

\section{Results and discussion}

The study optimized the color removal efficiency of the coagulant PAC considering the parameters including coagulant dose, agitation speed, $\mathrm{pH}$ and temperature. It also analyzed some physicochemical parameters of textile dyeing effluents and the results were compared with the national standard discharge limits of the effluents. The study results are described below: 
Fig. 1 Stepwise conversion of the tri-positive aluminum ion to the negative aluminate ion

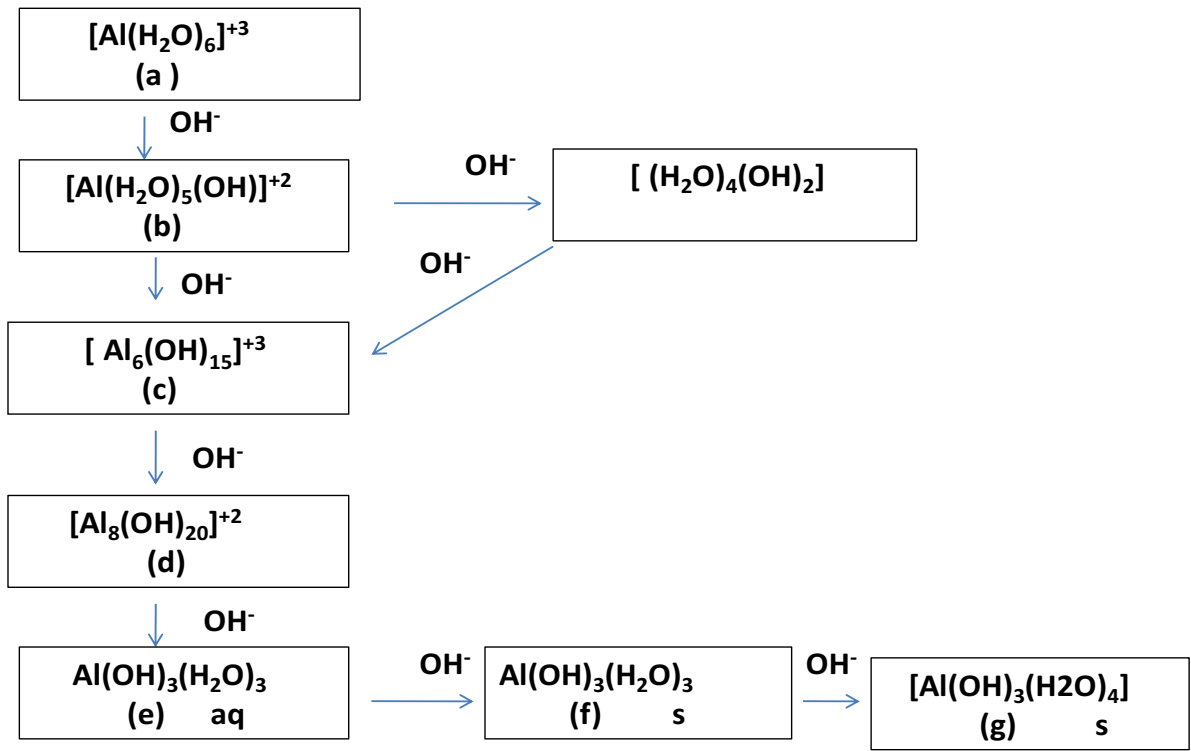

\section{Optimized color removal efficiency}

\section{Effect of coagulant dose}

In the study, the effect of coagulant dose on color removal efficiency of doses of PAC on three effluent samples. The results showed that the color removal efficiency increased in the beginning with dose concentration and then decreased slowly with doses for all the effluents (Fig. 2).It is noted that the color removal efficiency at low doses resembled well with the neutralization ability of coagulants. A number of reports showed that the coagulation-flocculation phenomenon was likely to be recognized to charge neutralization (sharp et al. 2006; Wei et al. 2010). By increasing doses, the positive charge of the coagulants became more dominant, which led to electrostatic repulsion between particles. As a result, the color removal efficiency of the coagulants decreases with the increasing of doses because of destabilization of colloids (Cohen and Hannah 1971). The maximum efficiency of coagulant PAC was observed to be near about $93 \%$ at a dose $100 \mathrm{mg} / \mathrm{L}$. The results indicated that PAC has potentially remove color from the effluents.

\section{Effect of mixing speed}

Mixing speed is one of the important factors in achieving higher color removal efficiency of the coagulants during the coagulation process. In this study, the effects of agitation speed between 30 and $150 \mathrm{rpm}$ were investigated. The results showed that the color removal efficiency of PAC in three different effluent samples increased with the increasing mixing speed between 30 and $70 \mathrm{rpm}$, except for the effluent Ef3( Fig. 3). These results might be caused by the effect of fast flocs formation and sludge precipitation rate of the inorganic coagulant with azo bone structure in drimarene red. A similar observed was made by Tasti et al. (2003). The
Fig. 2 Effect of coagulant doses on the color removal efficiency of the effluents $(\mathrm{pH}=7.0$, agitation speed $60 \mathrm{rpm}$ and temperature $30^{\circ} \mathrm{C}$ for PAC coagulant)

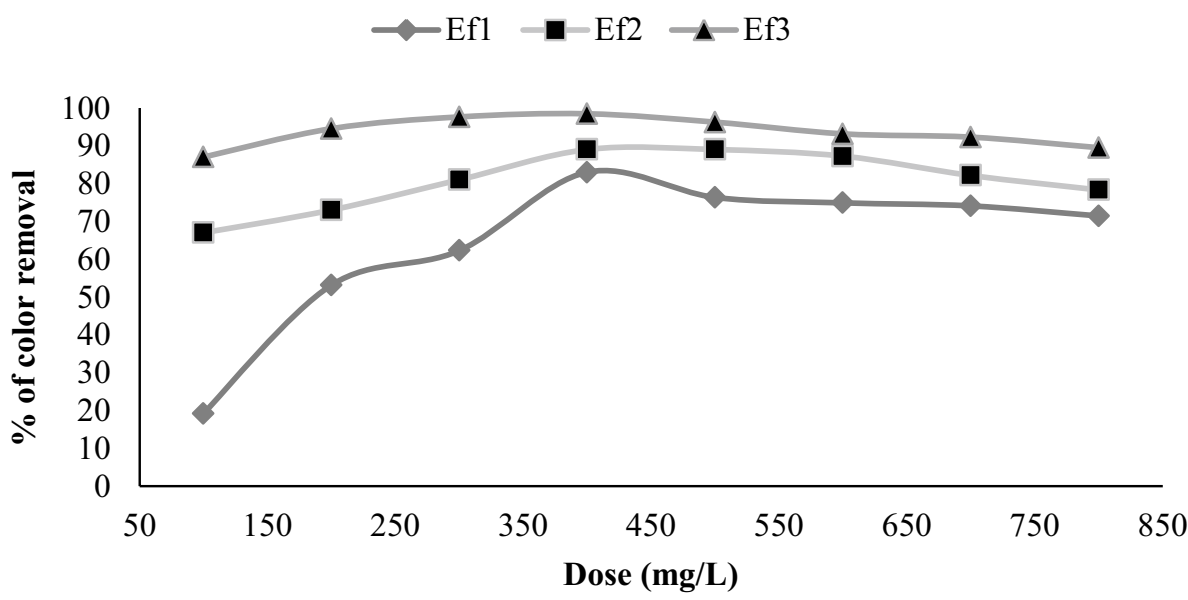

Dose (mg/L) 
Fig. 3 Effect of mixing speed on the color removal efficiency of the coagulants from the textile dyeing effluents $(\mathrm{pH}=7.0$, coagulant dose $300 \mathrm{mg} / \mathrm{Land}$ temperature $30{ }^{\circ} \mathrm{C}$ for PAC coagulant)

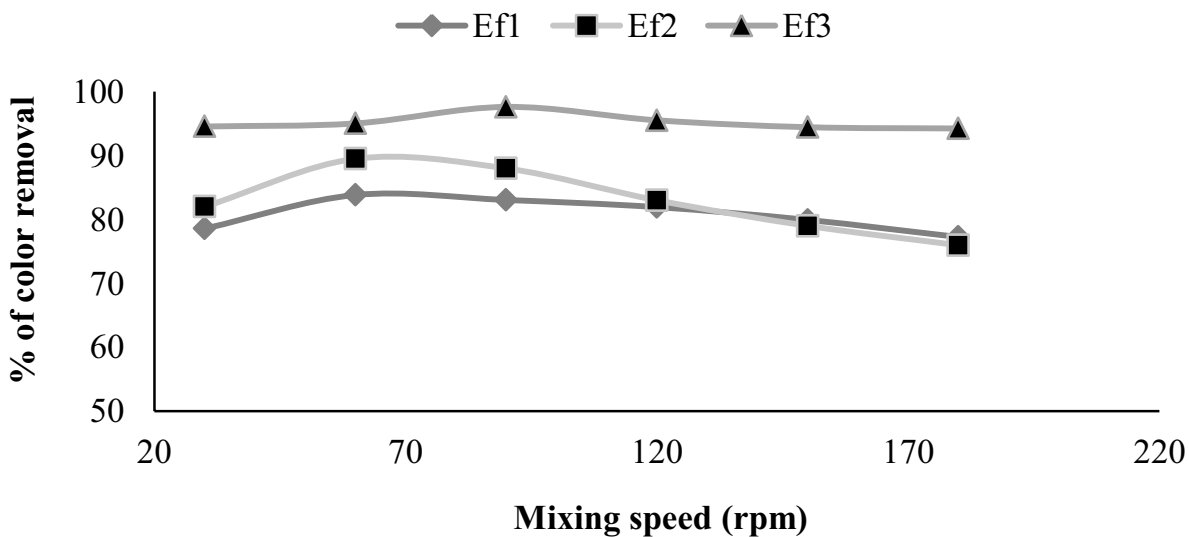

color removal efficiency of PAC gradually decreased as the agitation speed increased. This trend showed that floc formation and breakage were intensely affected by the mixing rate (Xu et al. 2010). The highest color removal might be caused of increasing of the shear stress and breakage of flocs with increasing agitation speed. The results showed that the optimum speed achieved was at $60 \mathrm{rpm}$ and the color removal efficiency was about $94 \%$ for effluent Ef3.

\section{Effect of $\mathrm{pH}$}

The $\mathrm{pH}$ has a major role in the unaccompanied coagulation process (Perng and Bui 2014). The $\mathrm{pH}$ variation influences the charge on hydrolysis products and precipitation of metal hydroxides. It must be required to control the $\mathrm{pH}$ of the solution to get the optimum efficiency of the coagulants ( $\mathrm{Li}$ and Gregory 1991). The illustrated that the color removal efficiency of the coagulant as a function of $\mathrm{pH}$. The maximum color removal efficiency of the coagulant obtained was about 93.84\% at pH 5. The coagulant showed the highest color removal efficiency among the three effluents was about $94 \%$ at $\mathrm{pH} 4.5$ and 8 (Fig. 4). However, the results showed that the coagulant, PAC was more active in an acidic $\mathrm{pH}$ range for all the three effluents to remove color from the wastewater.
Similar observations were reported by Jiang (2001) and Ye et al. (2007), which supported the present findings.

\section{Effect of temperature}

Temperature affects the solubility of the metal hydroxide precipitate and the rate of formation of the metal hydrolysis products. The results illustrated that the color removal efficiencies of the coagulant increased with increasing temperature for all the effluent samples (Fig. 5). The highest color removal efficiency of the coagulants PAC was about $94 \%$. The results indicated that the suitable temperature to flocculate of reactive dye wastewater was at room temperature $\left(30^{\circ} \mathrm{C}\right)$. A report showed that temperature has significantly affected the turbidity and particle counts during coagulation (Braul et al. 2001). A number of researchers reported that the color removing and dissolved organic carbon (DOC) of the dyeing solution are not sensitive to temperature (Knocke et al. 1986; Randtke 1998). Therefore, PAC is more suitable for the color removal from synthetic dyeing wastewater as compare to $\mathrm{FeCl}_{3}$ coagulants at room temperature.

The color removal efficiency study observed that the coagulant PAC removed the color from 85 to $95 \%$ of three dyeing effluents at a $300 \mathrm{mg} / \mathrm{L}$ coagulant dose, $60 \mathrm{rpm}$
Fig. 4 Effect of pH on the color removal efficiency of the coagulant from textile dyeing effluents (coagulant dose $300 \mathrm{mg} / \mathrm{L}$, agitation speed $60 \mathrm{rpm}$ and temperature $30{ }^{\circ} \mathrm{C}$ for PAC coagulant)

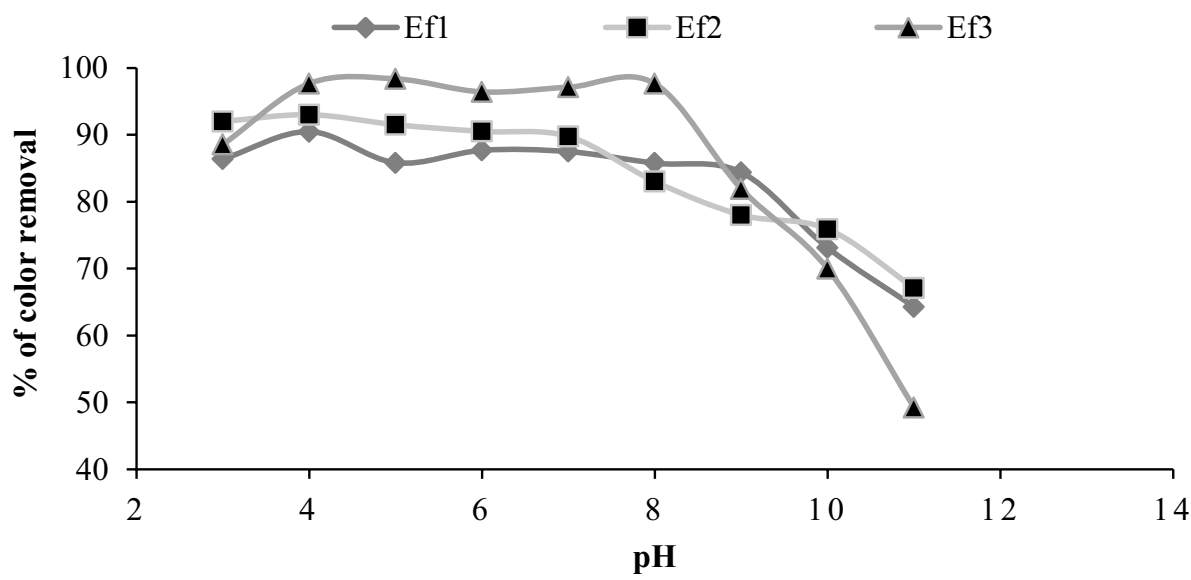

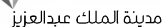

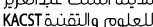


Fig. 5 Effect of temperature on the color removal efficiency of the coagulant from the textile dyeing effluents $(\mathrm{pH}=7.65$, 6.70 and 8.10 of the Ef1, Ef2 and Ef3, respectively, coagulant dose $300 \mathrm{mg} / \mathrm{L}$ and agitation speed $60 \mathrm{rpm}$ for PAC coagulant)

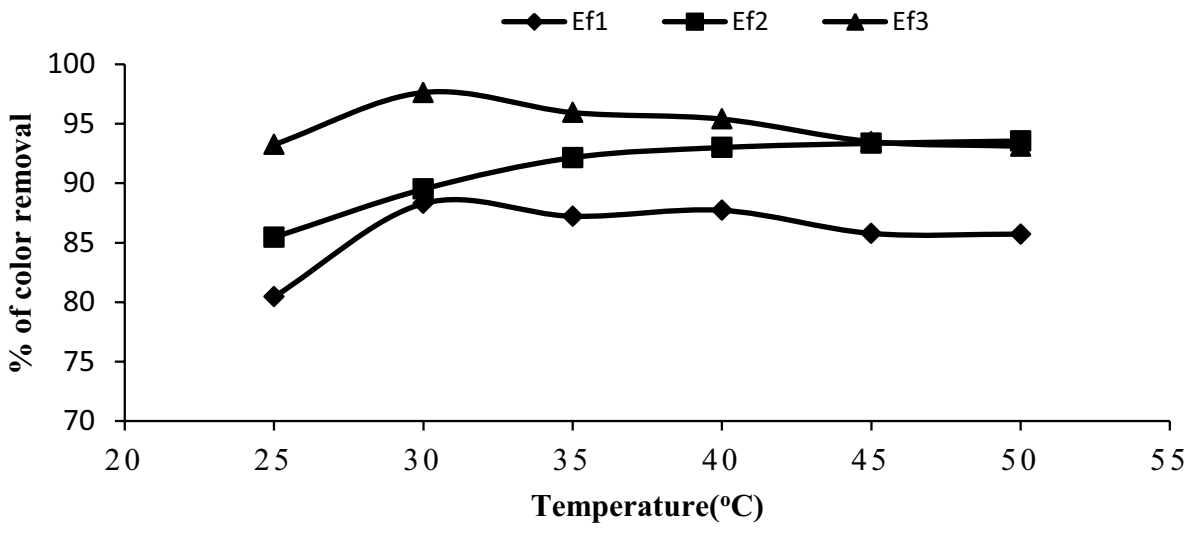

Table $1 \mathrm{pH}$ of textile effluents before and after treatment

\begin{tabular}{llll}
\hline Sample name & $\begin{array}{l}\mathrm{pH} \text { before } \\
\text { treatment }\end{array}$ & $\begin{array}{l}\mathrm{pH} \text { after treat- } \\
\text { ment with PAC }\end{array}$ & DoE* Standard \\
\hline Ef1 & 7.65 & 6.5 & $6-9$ \\
Ef2 & 6.70 & 6.75 & \\
Ef3 & 8.10 & 7.10 & \\
\hline
\end{tabular}

*Department of Environment, Bangladesh

speed, $30{ }^{\circ} \mathrm{C}$ temperature, and acidic range between 6 and 7 indicated the potentiality of the coagulant.

\section{Characterization and removal efficiency of physicochemical parameters}

$\mathrm{pH}$

The $\mathrm{pH}$ is one of the most significant effluent discharge quality parameters of an industry (Banerji 1993). Some chemical reactions such as solubility and metal toxicity are affected by the $\mathrm{pH}$ of the discharged effluents. The $\mathrm{pH}$ of the effluents also helps to establish the equilibrium between free $\mathrm{CO}_{2}$, $\mathrm{HCO}_{3}{ }^{-}$, and $\mathrm{CO}_{3}{ }^{-}$(Patel et al. 2015). Table 1 shows that the $\mathrm{pH}$ of textile effluent samples varied from 6.70 to 8.10 with a mean value of 7.48 indicating the alkalinity of the effluent samples. The results were similar to the study conducted by Imtiazuddin et al. (2012). The $\mathrm{pH}$ was found to be neutral range after treating the samples with PAC.

\section{Electrical conductivity}

The EC is indicating dissolved substances in an aqueous system. It depends on the dissociation of ions, their concentration, temperature, and migration in the electric field, but it does not give any idea about the type of ions present (Rump 1992). The electrical conductivity (EC) of textile dyeing effluents before and after treatment is given in Table 2. Before treatment, it was 5640, 4590 and $4150 \mu \mathrm{S} /$
Table 2 Electrical conductivity (EC) of textile effluents

\begin{tabular}{lllll}
\hline $\begin{array}{l}\text { Sample } \\
\text { name }\end{array}$ & $\begin{array}{l}\text { EC }(\mu \mathrm{S} / \\
\mathrm{cm}) \text { before } \\
\text { teatment }\end{array}$ & $\begin{array}{l}\mathrm{EC}(\mu \mathrm{S} / \mathrm{cm}) \\
\text { after treat- } \\
\text { ment with } \\
\text { PAC }\end{array}$ & $\begin{array}{l}\text { DoE stand- } \\
\text { ard EC }(\mu \mathrm{S} / \\
\mathrm{cm})\end{array}$ & $\begin{array}{l}\text { \% of decrease } \\
\text { of EC after } \\
\text { treatment } \\
\text { with PAC }\end{array}$ \\
\hline Ef1 & 5640 & 1080 & 1200 & 80.85 \\
Ef2 & 4590 & 750 & & 83.66 \\
Ef3 & 4150 & 1138 & & 72.57 \\
\hline
\end{tabular}

Table 3 Total dissolved solids (TDS) of textile effluents

\begin{tabular}{lllll}
\hline Sample name & $\begin{array}{l}\text { TDS (mg/L) } \\
\text { before treat- } \\
\text { ment }\end{array}$ & $\begin{array}{l}\text { TDS (mg/L) after } \\
\text { treatment with } \\
\text { PAC }\end{array}$ & $\begin{array}{l}\text { DoE } \\
\text { standard } \\
(\mathrm{mg} / \mathrm{L})\end{array}$ & \\
\hline Ef1 & 3778 & & 910 & 2100 \\
Ef2 & 2937.5 & 470 & & \\
Ef3 & 3350 & 479 & & \\
\hline
\end{tabular}

$\mathrm{cm}$, respectively, those were higher as per DoE (Department of Environment) standards permissible limits indicating the high levels of pollution. The results are similar to the report published by Kamal et al. results (2016). After the treatment, EC values went below the discharge limits of the DoE standards indicating the suitability of the coagulant PAC for the dyeing effluent.

\section{Total dissolved Solids (TDS)}

The amount of total dissolved solids (TDS) in different textile dyeing effluent samples were found to be $3778,2937.5$ and $3350 \mathrm{mg} / \mathrm{L}$, respectively (Table 3 ). The results showed that the TDS of the effluents was found higher indicating the discharged effluents have the potential to deteriorate the surface water quality and aquatic life as well. A similar observation was made by Imtiazuddin et al. (2012). The highest level of TDS was found in the EF1, which was collected from Norsindi area indicated that the area is severally polluted 
Fig. 6 Percentage removal of TDS, TSS and COD from effluents after treatment with PAC coagulant

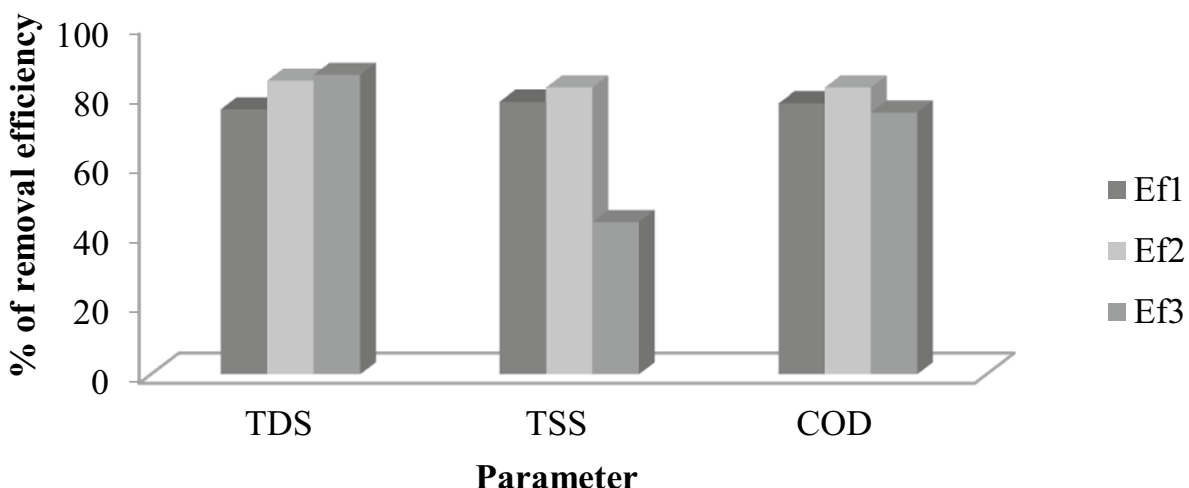

Table 4 Total suspended solids (TSS) of textile effluents

\begin{tabular}{llll}
\hline Sample name & $\begin{array}{l}\text { TSS }(\mathrm{mg} / \mathrm{L}) \\
\text { before treatment }\end{array}$ & $\begin{array}{l}\text { TSS (mg/L) after } \\
\text { treatment with PAC }\end{array}$ & $\begin{array}{l}\text { DoE } \\
\text { standard } \\
(\mathrm{mg} / \mathrm{L})\end{array}$ \\
\hline Ef1 & 401 & 88 & 150 \\
Ef2 & 340 & 61 & \\
Ef3 & 233 & 132 & \\
\hline
\end{tabular}

compared to the other two areas. The textile dyeing effluents with high TDS value may raise salinity troubles due to discharge to irrigation water (Kolhe and Pawar 2011). After treatment, the effluent samples with PAC, a decrease in TDS level was found to be $75.91,84$, and $85.70 \%$, respectively (Fig. 6). The TDS removal percentage of the present study was higher than the other two studies conducted by Solanki et al., (2013) and Khatmode and Thakare (2015) reported that the percentage of TDS removal of the textile dyeing effluents was about 62.5 and 27 by using PAC coagulant and sawdust adsorbent, respectively. Kumar (1989) stated that the allowable range of TDS in textile dyeing effluents was $1850-2000 \mathrm{mg} / \mathrm{L}$ for agriculture uses. The results illustrated that the TDS values in the effluents might change the taste and/or odors. The textile dyeing effluent must be treated before releasing it to the surface water bodies.

\section{Total suspended solids (TSS)}

The total suspended solids (TSS) of various textile dyeing effluent samples was found to be in the range of 401-233 mg/L, which was notably higher than the permissible limit of TSS $(150 \mathrm{mg} / \mathrm{L})$ as per DoE and EPA standard in textile dyeing effluents (Table 4). Several reports showed that the TSS of some textile dyeing effluents was varied from 100 to $390 \mathrm{mg} / \mathrm{L}$ (Mannuf et al. 2014). The TSS value of the treated effluent samples showed tremendous results reduced from 43 to $82 \%$ in three different effluent samples. (Fig. 6). Aleem et al. (2016) stated that the TSS removal by Alum
Table 5 Biological oxygen demand (BOD) of textile effluents

\begin{tabular}{llll}
\hline Sample name & $\begin{array}{l}\text { BOD (mg/L) } \\
\text { before treatment }\end{array}$ & $\begin{array}{l}\text { BOD (mg/L) after } \\
\text { treatment with PAC }\end{array}$ & $\begin{array}{l}\text { DoE } \\
\text { standard } \\
(\mathrm{mg} / \mathrm{L})\end{array}$ \\
\hline Ef1 & 272 & 45 & 50 \\
Ef2 & 117 & 29 & \\
Ef3 & 192 & 47 & \\
\hline
\end{tabular}

was about $62 \%$ of textile effluents of Pakistan, which was lower than the results of the present study. PAC has a better TSS removal capacity.

\section{Biological oxygen demand (BOD)}

Biological oxygen demand (BOD) measures the amount of oxygen used by microorganisms in the biological process in water. The results shows that the BOD value of Ef1, Ef2, and Ef3 were 272, 117, and $197 \mathrm{mg} / \mathrm{L}$, respectively, obtained before treatment (Table 5). This observation was found to be similar to the study conducted by Imtiazuddin et al. (2012). After treatment, the BOD values were 83.45, 75.21 and $76.14 \%$ for Ef1, Ef2, and Ef3, respectively. Patel and Vashi (2010) stated that the BOD of textile effluent was reduced to $51.4 \%$ after treatment with ferric sulfate coagulant which is lower than the present study. Hence, PAC is the most efficient coagulant for the textile dyeing effluents.

\section{Chemical oxygen demand (COD)}

Chemical oxygen demand (COD) shows the presence of all organic and inorganic matter content in the textile dyeing effluents. It comprises both the biodegradable and nonbiodegradable portions of live bacterial attack, but it can be oxidized by strong chemical oxidants (Abbasi 1998; Tan et al. 2000; Chiron et al. 2000). Table 6 illustrates the total COD in various textile effluents was found to be 784 , 340 , and $512 \mathrm{mg} / \mathrm{L}$, respectively, indicating a higher level 
Table 6 Chemical oxygen demand (COD) of textile effluents

\begin{tabular}{llll}
\hline Sample name & $\begin{array}{l}\text { COD }(\mathrm{mg} / \mathrm{L}) \\
\text { before treatment }\end{array}$ & $\begin{array}{l}\text { COD }(\mathrm{mg} / \mathrm{L}) \text { after } \\
\text { treatment with } \\
\text { PAC }\end{array}$ & $\begin{array}{l}\text { DoE standard } \\
\text { COD }(\mathrm{mg} / \mathrm{L})\end{array}$ \\
\hline Ef1 & 784 & 176 & 200 \\
Ef2 & 340 & 61 & \\
Ef3 & 512 & 128 & \\
\hline
\end{tabular}

Table 7 Concentration of chloride ions of textile dyeing effluents

\begin{tabular}{llll}
\hline Sample name & $\begin{array}{l}\text { Chloride ions } \\
(\mathrm{mg} / \mathrm{L}) \text { before } \\
\text { treatment }\end{array}$ & $\begin{array}{l}\text { Chloride ions } \\
(\mathrm{mg} / \mathrm{L}) \text { after } \\
\text { treatment with } \\
\text { PAC }\end{array}$ & $\begin{array}{l}\text { DoE standard } \\
(\mathrm{mg} / \mathrm{L})\end{array}$ \\
\hline Ef1 & 654.95 & 304.91 & $400-600$ \\
Ef2 & 337.96 & 111.83 & \\
Ef & 126.74 & 78.92 & \\
\hline
\end{tabular}

of pollution. Morshed et al. (2016) reported that the COD of untreated textile effluents was found between 301 and $359 \mathrm{mg} / \mathrm{l}$, which were lower than the present findings. The highest COD value was observed in sample, Ef1 and the lowest was found in sample Ef2. After treating the effluent samples with PAC, the reduction of COD was found to be $77.55,82.05$, and $75 \%$, respectively (Fig. 6). The removal of COD from the textile dyeing effluents was higher than the studies conducted by Patel and Vashi (2010), where the removal was $55.2 \%$ treated with ferric sulfate coagulant.

\section{Concentration of chloride ions}

Almost all-natural waters contain chloride and sulfate ions. The EPA standard recommends a maximum concentration of chloride in water is $250 \mathrm{mg} / \mathrm{L}$. The lower and higher than the permissible limits might create harm for human beings. Table 7 shows that chloride contents of textile dyeing effluents were $654.95,337.96$, and $126.74 \mathrm{mg} / \mathrm{L}$, respectively,
Table 8 Concentration of bicarbonate ions of textile dyeing effluents

\begin{tabular}{llll}
\hline Sample name & $\begin{array}{l}\text { Bicarbonate ions } \\
(\mathrm{mg} / \mathrm{L}) \text { before } \\
\text { treatment }\end{array}$ & $\begin{array}{l}\text { Bicarbonate ions } \\
(\mathrm{mg} / \mathrm{L}) \text { after } \\
\text { treatment with } \\
\text { PAC }\end{array}$ & $\begin{array}{l}\text { DoE Standard } \\
(\mathrm{mg} / \mathrm{L})\end{array}$ \\
\hline Ef1 & 360 & 200 & 300 \\
Ef2 & 425 & 185 & \\
Ef3 & 475 & 230 & \\
\hline
\end{tabular}

in three effluent samples. The chloride concentration in the effluent samples found lower than the DoE standard except for the Ef1.

Aleem et al. (2016) reported that the concentration of chloride of the untreated effluents was $432 \mathrm{mg} / \mathrm{l}$, which was lower than the study results indicating a lower level of pollution. After treating the effluent with PAC, the chloride concentration in all the effluents was found below the DoE standard limit and these were $53.45,66.91$, and $37.73 \%$ for Ef1, Ef2, and Ef3, respectively (Fig. 7). A report showed that the removal percentage of chloride was $53.94 \%$ after treated with ferric chloride coagulant (Metha 2013), which was almost the same as the present study findings.

\section{Concentration of bicarbonate ions}

The lower amounts of bicarbonate ions in water are not considered for pollution but the higher concentration decreases the water quality level. The DoE standard recommends a maximum concentration of $300 \mathrm{mg} / \mathrm{l}$ for bicarbonate ions (Dey and Islam 2012). Table 8 shows that the bicarbonate ion concentration in textile dyeing effluents was 654.95 , 337.96 , and $126.74 \mathrm{mg} / \mathrm{l}$, respectively, indicating a low level of pollution.

Only the effluent sample (Ef1) exceeded the DoE standard limits. After treating the effluent with PAC, the concentration of decrease in bicarbonate concentration was considerable and was 44.4., 56.5, and 51.6\%, respectively, for different
Fig. 7 Percentage removal of $\mathrm{Cl}^{-}, \mathrm{HCO}_{3}^{-}$and $\mathrm{SO}_{4}{ }^{2-}$ ions from effluents after treatment with PAC coagulant

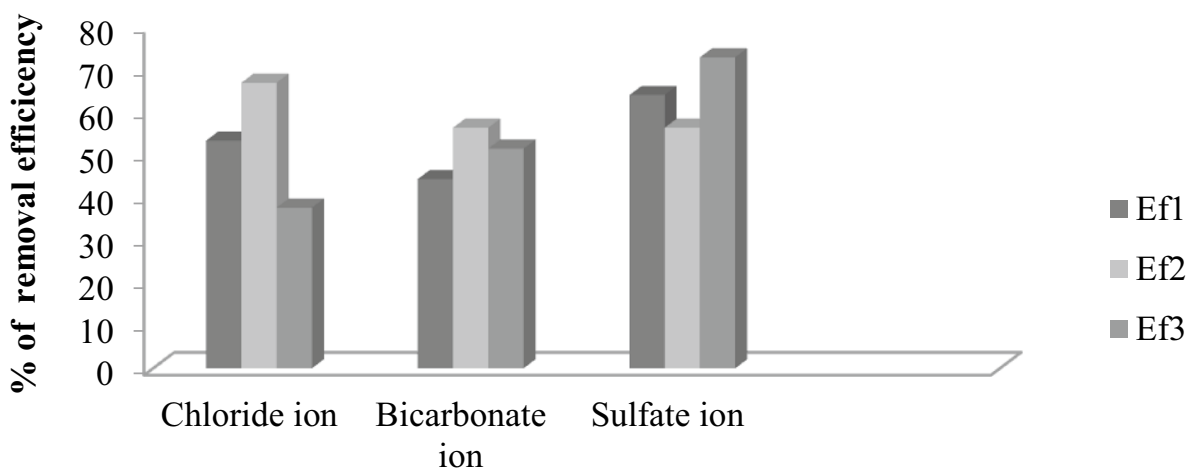

Anionic parameters 
effluent samples (Fig. 7). Hussian et al. (2004) studied that the higher concentration of bicarbonate ions was found in four textile dyeing effluents, and this observation is similar to the present findings.

\section{Concentration of sulfate ions}

Most of the natural water supplies contain sulfates $\left(\mathrm{SO}_{4}{ }^{2-}\right)$, which has no color and odor. These are compounds of sulfur and oxygen and stay as a dissolved salt in water. Sulfates can be more worrying because they usually take place in larger concentrations. The amount of sulfate ions in various textile effluent samples was shown to be in the range of 448 , 638, and $434 \mathrm{mg} / \mathrm{L}$, respectively (Table 9). According to WHO, the maximum permissible concentration of sulfate is $400 \mathrm{mg} / \mathrm{L}$ and except for the sample (Ef2), the sulfate concentration in the other two samples was well below the permissible standard. After treating the effluent samples with PAC, the sulfate ions concentrations found in the samples were $64.06,65.72$, and $72.88 \%$, respectively, indicated that the coagulant PAC successfully reduced sulfate ions from the effluents (Fig. 7). Aleem et al. (2016) depicted that the concentration of sulfate ion in textile dyeing effluents was increased after coagulation with alum; however, the present study results showed the reduced concentration after treated with PAC.

Agarwal (1996) stated that the textile effluents containing sulfate ions should not be discarded into water bodies from where water is supplied for consumption, as a higher concentration of sulfate ions might change the taste. The sulfate ions have a laxative effect on domestic animals and humans and are generally related to high hardness levels.

\section{Some heavy metals of textile dyeing effluents}

The concentration of heavy metals including $\mathrm{Cr}, \mathrm{Mn}, \mathrm{Fe}, \mathrm{Cu}$, $\mathrm{Zn}$ and $\mathrm{Pb}$ in dyeing effluent samples is shown in Table 10. The concentrations of these heavy metals were lower than the national quality discharge standard limits for the textile dyeing effluents expect the concentration of $\mathrm{Fe}$ and $\mathrm{Pb}$ as stated by Dey and Islam (2012). The Fe concentrations of the samples Ef1, Ef2, and Ef3 were 4.2826, 3.6188, and $2.891 \mathrm{mg} / \mathrm{L}$, respectively. Before treatment, the $\mathrm{Pb}$ concentration of Ef3 was $0.2900 \mathrm{mg} / \mathrm{L}$, which was higher than standard limits. The concentrations of Fe of the samples Ef1, Ef2, and Ef3 decreased to 72.7, 64.85, and 71.92\%, respectively, and the concentration of $\mathrm{Pb}$ of the samples were decreased to $79.2,47.7$ and $98.5 \%$, respectively, after treatment with PAC coagulant (not shown in Table). The study optimized the parameters of the coagulation process and illustrated that coagulation with PAC was potentially reduced $\mathrm{Fe}$ and $\mathrm{Pb}$. Hence, the PAC coagulant is very much active against heavy metals removing from the dyeing effluent.

\section{Conclusions}

The color removal efficiency study observed that the coagulant PAC removed the color from 85 to $95 \%$ of three dyeing effluents at a $300 \mathrm{mg} / \mathrm{L}$ coagulant dose, $60 \mathrm{rpm}$ speed, $30{ }^{\circ} \mathrm{C}$
Table 9 Concentration of sulfates $\left(\mathrm{SO}_{4}{ }^{2-}\right)$ of textile effluents

Table 10 Concentration of some heavy metals of textile dyeing effluents

\begin{tabular}{lllc}
\hline Sample name & $\begin{array}{l}\text { Sulfate ions }(\mathrm{mg} / \mathrm{L}) \\
\text { concentration }(\mathrm{mg} / \mathrm{L}) \text { before } \\
\text { treatment }\end{array}$ & $\begin{array}{l}\text { Sulfate ions }(\mathrm{mg} / \mathrm{L}) \\
\text { concentration }(\mathrm{mg} / \mathrm{L}) \text { after treat- } \\
\text { ment with PAC }\end{array}$ & DoE standard \\
\hline Ef1 & 448 & 161 & $400-600$ \\
Ef2 & 638 & 218.67 & \\
Ef3 & 434 & 117.7 & \\
\hline
\end{tabular}

\begin{tabular}{|c|c|c|c|c|c|c|c|}
\hline \multirow{3}{*}{$\begin{array}{l}\text { Parameters } \\
\text { Concentration (mg/L) }\end{array}$} & \multicolumn{6}{|l|}{ Results } & \multirow{3}{*}{$\begin{array}{l}\text { DoE standarc } \\
-\end{array}$} \\
\hline & \multicolumn{3}{|c|}{ Before treatment } & \multicolumn{3}{|c|}{ After treatment with PAC } & \\
\hline & Ef1 & Ef2 & Ef3 & Ef1 & Ef2 & Ef3 & \\
\hline $\mathrm{Cr}$ & 0.1334 & 0.0320 & 0.0355 & 0.0028 & 0.0166 & 0.0092 & 0.5 \\
\hline Mn & 0.1977 & 0.1722 & 0.4119 & 0.1349 & 0.2205 & 0.2755 & 5 \\
\hline $\mathrm{Fe}$ & 4.2826 & 3.6188 & 2.8911 & 1.1900 & 1.2719 & 0.8190 & 2 \\
\hline $\mathrm{Cu}$ & 0.0479 & 0.0790 & 0.0470 & 0.0209 & 0.0590 & 0.0068 & 0.5 \\
\hline $\mathrm{Zn}$ & 0.2585 & 0.2047 & 0.1648 & 0.0558 & 0.0560 & 0.0400 & 5 \\
\hline $\mathrm{Pb}$ & 0.0621 & 0.0086 & 0.2900 & 0.0129 & 0.0045 & 0.0043 & 0.1 \\
\hline
\end{tabular}


temperature, and acidic range between 6 and 7 indicated the potentiality of the coagulant. The study results revealed that the concentration of different parameters of textile dyeing effluents such as EC, TDS, TSS, BOD, COD, and anions was found higher than the standard guidelines for effluent discharged. The study results showed a noteworthy decrease in all physicochemical parameters including $\mathrm{pH}, \mathrm{EC}$, TDS, TSS, COD, BOD $, \mathrm{Cl}^{-}, \mathrm{HCO}_{3}{ }^{-}$, and $\mathrm{SO}_{4}{ }^{2-}$. Among the heavy metals of the textile dyeing effluents, $\mathrm{Fe}$ and $\mathrm{Pb}$ exceed the national discharge standard limits of the effluents. The coagulant PAC also successfully reduced heavy metals like $\mathrm{Fe}$ and $\mathrm{Pb}$ by 65 to $72 \%$ and 48 to $95 \%$, respectively. After treatment with PAC, the concentrations of heavy metals in the textile dyeing effluents were found lower than the DoE standard for the discharge limits of the textile effluents. The study results showed that the PAC is a potential coagulant for reducing the concentration of several physicochemical parameters from textile dyeing effluents. It is difficult to degrade the dyeing effluent using a single treatment unit such as physical, chemical, and biological. Therefore, the study suggested a combination of the units for achieving a higher degradation of the effluents.

Acknowledgements The authors are thankful to the Ministry of Science and Technology, Government of the People's Republic of Bangladesh, for partial funding of this study (Grant No. SL. 414, Gr. SL. $34 \mathrm{ES}$ ). One of the authors would like to thank the University Grants Commission, Bangladesh, for granting the fellowship.

\section{Compliance with ethical standards}

Conflict of interest The authors declare that there is no conflict of interest regarding the publication of this article.

Human and animal rights The authors ensured that there was no direct or indirect involvement of human, animal, or any biological elements have been tested that may arise any conflict of interest in this research. Moreover, the authors declare that they have no conflicts of interest in the subject matter or materials discussed in the manuscript.

Open Access This article is licensed under a Creative Commons Attribution 4.0 International License, which permits use, sharing, adaptation, distribution and reproduction in any medium or format, as long as you give appropriate credit to the original author(s) and the source, provide a link to the Creative Commons licence, and indicate if changes were made. The images or other third party material in this article are included in the article's Creative Commons licence, unless indicated otherwise in a credit line to the material. If material is not included in the article's Creative Commons licence and your intended use is not permitted by statutory regulation or exceeds the permitted use, you will need to obtain permission directly from the copyright holder. To view a copy of this licence, visit http://creativecommons.org/licenses/by/4.0/.

\section{References}

Abbasi SA (1998) Water quality sampling and analysis. Discovery Publishing House, Daryaganj

Agarwal SK (1996) Industrial environment (assessment and strategy). APH Publishing Corporation, New Delhi, p 276

Ahmad MN, Ram RN (1992) Removal of basic dye from waste water using silica as adsorbent. Environ Pollut 77:79

Alam M, Deb H, Guha AK (2016) An instigation to green manufacturing: characterization and analytical analysis of textile wastewater for physico-chemicaland organic pollution indicators. Am J Environ Sci Technol 1:11-12

Aleem M, Rashid H, Awan AN (2016) Characterization and removal of dyeing effluents by adsorption and coagulation methods. J Agric Res 54(1):97-106

American Public Health Association (APHA) (1989) Standard methods for the examination of water and wastewater, 17th edn. APHA, Washington, DC

Amirtharajah A, Mills KM (1982) Rapid mix design for mechanisms of alum coagulation. J AWWA 74:210-216

Anjaneyulu Y, Chary NS, Raj DSS (2005) Decolourization of industrial effluents available methods and emerging technologies. Environ Sci Biotech 4:245-273

Arnold EG, Clescerl LS, Eaton AD, American Public Health Association (APHA) (1992) Standard methods for the examination of water and wastewater, 18th edn. Washington, DC

Banerji KS (1993) Environmental chemistry. Prentice Hall of India Pvt Ltd, New Delhi, p 24

Belukear S, Jekel M (1993) Precipitation and coagulation of organic substances and colors from industrial waste water. Water Sci Technol 28:193-199

Bennett DH, Reeser D (1998) Pretreatment of CMTP effluent by lime to reduce ite and colour. In: Environmental conference, Charlston SC, pp. 199-207

Braul L, Viraraghavan T, Corkal D (2001) Cold water effects on enhanced coagulation of high DOC, low turbidity water. Water Qual Res J Can 36(4):701-717

Chiron S, Fernandez-Alba A, Rodriguez A, Garcia-Calvo E (2000) Pesticides chemical oxidation: state of the art. Water Res 34:366-377

Chrislarsen TH (1982) Comparison of methods for preparation of municipal compost for analysis of metals by atomic spectrophotometer. Int J Environ Anal Chem 12:211-221

Cohen JM, Hannah SA (1971) Water quality and treatment, 3rd edn. Mc Graw Hill, New York

Crini G (2006) Non-conventional low-cost adsorbents for dye removal: a review. Bio Resour Technol 97:1061-1085

Dennett KE, Amirtharajah A, Moran TF, Gould JP (1996) Coagulation: It's Effect on Organic Matter. J AWWA 88(4):129-142

Dey S, Islam A (2012) A review on textile wastewater characterization in Bangladesh. Resour Environ 5(1):15-44. https://doi. org/10.5923/j.re.20150501.03

Duizbek AM, Kowal AL (1983) Water treatment by Coagulation adsorption with dolomite, chemistry for protection of environment In: proceedings of international conference. Toulouse, France 205

Eren Z, Acar FN (2006) Adsorption of Reactive Black 5from an aqueous solution- equilibrium and kinetic studies. Desalination 194:1-10

Gao BY, Yue QY, Wang Y, Zhou WZ (2007) Colour removal from dye-containing wastewater by magnesium chloride. J Environ Manage 82:167-172

Gejdzicki B (1998) The dyeing process of textile made from polyester/ cellulose fiber yarn. In: Proceeding of the conference of dye and colorists', zakopane

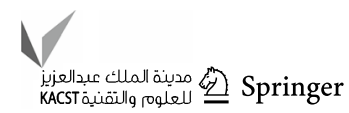


Golob V, Vinder A, Simonic M (2005) Efficiency of the coagulation/ flocculation method for the treatment of dye bath effluents. Dyes Pigm 67:93-97

Hussian J, Hussian I, Arif M (2004) Characterization of textile wastewater. J Ind Pollut Control 20(1):137-144

Imtiazuddin SM, Mumtaz M, Mallick KA (2012) Pollutants of wastewater characteristics in textile industries. J Basic App Sci 8:554-556

Islam MR, Mostafa MG (2018a) Removal of a Reactive Dye from Synthetic Wastewater Using PAC and $\mathrm{FeCl}_{3}$ coagulants. J. Life Earth Sci. 13:39-44

Islam MR, Mostafa MG (2018b) Textile dyeing effluents and environment concerns-a review. J Environ Sci Nat Resour 11(1):131-144

Jiang J (2001) Development of coagulation theory and pre-polymerized coagulants for water treatment. Sep Purif Methods 30:127-141

Kamal AKI, Ahmed F, Hassan M, Uddin MK, Hossain SM (2016) Characterization of textile effluents from dhaka export processing zone (DEPZ) Area in Dhaka, Bangladesh. Pollution 2(2):153-161

Khatmode NP, Thakare SB (2015) Removal of pH, TDS, TSS \& color from textile effluent by using sawdust as adsorbent. Int J Sci Basic Appl Res 24(2):158-163

Knocke WR, West S, Hoehn RC (1986) Effects of low temperature on the removal of trihalomethane precursors by coagulation. J AWWA 78(4):189-195

Kolhe AS, Pawar VP (2011) Physico-chemical analysis of effluents from dairy industry. Recent Res in Sci and Tech 3(5):29-32

Kumar A (1989) Environmental chemistry. Wiley, New Delhi, pp 261-264

Lalvo IG, Guerginov II, Krysteva MA, Fartosy K (2000) Treatment of wastewater from Distilleries with Chitosan. Water Res 34:1503-1506

Li G, Gregory J (1991) Flocculation and sedimentation of highturbidity waters. Water Res 25:1137-1143

Lin SH, Lin CM (1993) Treatment of textile waste effluents by ozonization and chemical coagulation. Water Res 27:1743-1748

Makia D, Fadaly HE, Zawawy ME (1999) Microbiological and chemical aspects on some fresh water samples. Pak J Biol Sci 2:1017-1023

Mehta P (2013) chemical treatment of textile dyeing effluents using ferric chloride as coagulant: an analysis. Int J Basic Appl Chem Sci 3(3):49-55

Morshed MN, Azad SA, Alam MAM, Deb H, Guha AK (2016) An instigation to green manufacturing: characterization and analytical analysis of textile wastewater for physico-chemicaland organic pollution indicators. Am J Environ Sci Technol 1:11-21

Munnaf A, Islam MS, Tusher TR, Kabir MH, Molla MAH (2014) Investigation of water quality parameters discharged from textile dyeing industries. J Environ Sci Nat Resour 7(1):257-263

Ozer A, Akkaya G, Turabik M (2006) The removal of Acid Red 274 from wastewater: Combined biosorptionand biocoagulation with 'Spirogyra rhizopus'. Dyes Pigm 71:83-89

Patel H, Vashi Rt (2010) Treatment of textile wastewater by adsorption and coagulation. E J Chem 7(4):1468-1476

Patel R, Tajddin K, Patel A, Patel B (2015) Physico-chemical analysis of textile effluent. IJRSI 5(2):33-37

Perng YS, Bui HM (2014) The feasibility of cassia fistula gum with polyaluminium chloride for decolourization of reactive dyeing wastewater. J Serb Chem Soc 79:1-26

Randtke SJ (1998) Organic contaminant removal by coagulation and related process combinations. J Am Water Works Assoc 80(5):40-56
Rump HH (1992) Laboratory manual for the examination of water, wastewater and soil, 2nd edn. VCH publishers, New York, pp 90-110

Saiful AS, Ghaniey LA, Suhardy D, Farizul HK, Irfan HMD (2005) Dye removal from aqueous solution by using adsorption on treated sugarcane bagasse'. Am J Appl Sci 2:1499-1503

Sangodoin AY (1991) Groundwater and Surface water pollution by open refuse dump in Ibadan Nigeria. J Discov Innov 3(1):24-31

Shah SFA, Ak S, Mehdi A, Memon AA, Harijan K, Ali ZM (2012) Analysis and treatment of industrial wastewater through chemical coagulation adsorption process - a case study of Clariant Pakistan limited. AIP Conf Proc 1453:353. https://doi.org/10.1063/1.47111 99

Shi B, Li G, Wang D, Feng C, Tang H (2007) Removal of direct dyes by coagulation- the performance of preformed polymeric aluminum species. J Haz Mat 143:567-574

Sharp EL, Jarvis P, Parsons SA, Jefferson B (2006) The impact of zeta potential on the physical properties of ferric-NOM flocs. Environ Sci Technol 40(12):3934-3940

Simeonov V, Simenov P, Samara C, Zachariadis G, Vousta D, Anthemidis A, Sofonious M, Kouimtzis T (2003) The assessment of the Surface water quality in northern Greece. Water Res 37(17):4119-4124

Soares GMB, Teresa M, Amorim P, Lageiro M, Ferreira MC (2006) Pilot-scale enzymatic decolourization of industrial dyeing process wastewater. Text Res J 76(1):4-11

Solanki M, Suresh S, Das SN, Shukla K (2013) Treatment of real textile wastewater using coagulation technology. Int J ChemTech Res 5(2):610-615

Stumn W, Morgan JJ (1962) Chemical Aspects of Coagulation. J AWWA 54(8):971-992

Tan BH, Teng TT, Omar AKM (2000) Removal of dyes and industrial wastes by Magnesium Chloride. Water Res 34:597-601

Tatsi AA, Zouboulis AI, Matis KA, Samaras P (2003) Coagulationflocculation pretreatment of sanitary landfill leachates. Chemosph 53(7):737-744

Vandevivere PC, Bianchi R, Verstraete W (1998) Treatment and reuse of wastewater from the textile wet-processing industry: review of emerging technologies. J Chem Technol Biotechn 72:289-293

Wang H, Su JQ, Zheng X, Tian Y, Xiong XJ, Zheng TL (2009a) Bacterial decolourization and degradation of the reactive dye Reactive red 180 by Citrobacter sp. CK3. Int Biodegr 63:395-399

Wang H, Zheng XW, Su JQ, Tian Y, Xiong XJ, Zheng TL (2009b) Biological decolourization of the reactive dyes Reactive Black 5 by a novel isolated bacterial strain Enterobacter sp. EC3. Hazard Mat 171:654-659

Wei JC, Gao BY, Yue QY, Wang Y (2010) Strength and regrowth properties of polyferric-polymer dual-coagulant flocs in surface water treatment. J Hazard Mat 175:949-954

Xu W, Gao B, Yue Q, Wang Y (2010) Effect of shear force and solution $\mathrm{pH}$ on flocs breakage and re-growth formed by nano-Al13 polymer. Water Res 44(6):1893-1899

Ye C, Wang D, Shi B, Yu J, Qu J, Edwards M, Tang H (2007) Alkalinity effect of coagulation with polyaluminum chlorides: role of electrostatic patch. Eng Aspects 294:163-173

Publisher's Note Springer Nature remains neutral with regard to jurisdictional claims in published maps and institutional affiliations. 